\title{
Animal Manure as a Nitrogen Source to Grass
}

\author{
Anderson de Moura Zanine, Daniele de Jesus Ferreira \\ Department of Animal Science, Federal University of Mato Grosso, Rondonópolis, Brazil \\ Email: andersonzanine@ufmt.br, dany dosanjos@yahoo.com.br
}

Received 17 March 2015; accepted 10 April 2015; published 13 April 2015

Copyright (C) 2015 by authors and Scientific Research Publishing Inc.

This work is licensed under the Creative Commons Attribution International License (CC BY). http://creativecommons.org/licenses/by/4.0/

c) (i) Open Access

\begin{abstract}
The use of animal manure has been studied increasingly in recent years due to the excess waste in confinements, which generates great amounts of animal excreta; and as a result of the worsening petroleum crisis, the cost of mineral fertilizing products has increased. Thus, studies point out the potential of this waste to improve biotic and abiotic soil condition and nutritional value of forage. Substances ingested by animals that resist the action of gastric enzymes are enriched with large amounts of bacteria, other microorganisms and other substances to form residual feces, the main component of manure, which, together with the wash water from barnyard urine, form the slurry. The volume of living or dead bacteria in the feces represents $20 \%$ of total manure and it is from these that a large amount of nitrogen originates as protein. Due to this potentiality, animal manure can be used as an input in agriculture, impacting positively on production and forage productivity, and having a favorable effect on the environment.
\end{abstract}

\section{Keywords}

Handling, Organic Matter, Organic System, Slurry

\section{Introduction}

The socio-economic and environmental sustainability of agriculture is a real concern to those involved in agribusiness. In this context, ecological trends (organic, biological, biodynamic, natural, etc.) originate from the growing global concerns, particularly in industrialized countries, with a range of issues related to environmental degradation and consumption habits. A common point among these proposals or alternative strands is the sole purpose to develop balanced, socially fair and economically viable agriculture and livestock.

Organic agriculture and livestock are models of production that have been growing in recent years in Europe and Brazil, with their essence simplicity and harmony with the environment, and without neglecting productivity 
or producer profitability.

Conventional agriculture uses non-renewable resources and industrialized input in an extractivist way. This causes a considerable increase in production costs, as well as harms the environment. There is a need to evaluate alternatives which do not degrade the environment and maintain the current levels of productivity. Among the available alternatives, the use of animal manure has aroused interest in the scientific community due to the diverse properties of its composition and its availability in areas of high animal density.

The first studies on the use of animal manure on forage in Brazil were carried out in the Federal University of Santa Maria, on natural pasture, where an increase of $307 \%$ in dry matter production was obtained when manure was repeatedly applied $40 \mathrm{~m}^{3} / \mathrm{ha}^{1}$, whereas, in the center of the country, applying $150 \mathrm{~m} /$ ha/year, the production of Brachiaria brizantha cv Marandu achieved an increase of 156\% compared with the pasture with no animal manure application [1]-[3].

The liquid slurry that results from washing stables, barns, milking parlors, hutches and pens, is generally easily found in places that breed pigs, dairy cattle and feedlots. In this way, it can be recognized as an alternative source for nitrogen $(\mathrm{N})$ by Brazilian farmers and ranchers, although further studies are about its chemical composition of phosphorus $(\mathrm{P})$, potassium $(\mathrm{K})$, calcium $(\mathrm{Ca})$, magnesium $(\mathrm{Mg})$, manganese $(\mathrm{Mn})$ and zinc $(\mathrm{Zn})$; the adequate time for use in crops and pastures, the application period, and the amount to be used are required. It can economically replace the need for fertilizer in forage production [4]-[7].

There are not many producers dedicated to dairy or beef cattle that use manure from cattle or pigs as fertilizer. In most places, the manure produced accumulates around the stables or is released into water sources causing contamination with fecal coliforms, promoting the reduction of water oxygen levels, and consequently seriously compromising the ecological balance [8]-[10].

Nitrogen is one of the major limiting nutrients for the increase, or maintenance of productivity of crops in tropical soils, due to its complex dynamic and costs, which leads the search for viable alternatives to minimize the need for application, and to extend its availability time for the plants [11] [12]. Therefore, the need to fertilize pasture, in view of high costs of fertilizers, causes farmers to think about the maximization of existent resources naturally found on rural properties.

Nitrogen fertilizers are more expensive and mainly arise from petrochemical sources, representing a major limitation to forage. Nitrogen is the most abundant nutrient in manure. The value of animal manure in fertilization is so great that in some countries in Europe (i.e. Switzerland, Spain, and Austria), it is required by law to capture, store, and transport in appropriate tanks, and to distribute in crop or pasture areas [13]-[18].

In the "new" livestock scenario, through the increase of organic production importance, it is, therefore, necessary to study rational use of manure as an alternative to enable forage production, in an organic or traditional method of ruminant feeding. Despite the momentum generated by this demand in recent years, organic production is not still considered a current way to trigger ecologic groups, although it provides a tangible reality to offer healthy products to consumers and a profitable activity for producers [6] [19]-[22].

As a result, the scope of this review aims to show the potential of manure as a nitrogen source for the production of forage.

\section{Nitrogen Dynamics}

After phosphorus, nitrogen is the nutrient that is most required by plants during pasture formation; and it is responsible for the number of tills, root growth, various enzymatic processes, increasing the amount and nutritional quality of grasses and, with the exception of legumes, it the most often supplied in unsatisfactory amounts [23].

According to [24], nitrogen content in the soil can influence forage handling in relation to the death of old leaves, the levels of reserves for regrowth, the growth of the root system, the competition between plants and the nutritive value of forages. It is one of the most dynamic elements that is known, and because of its quick chemical and biochemical transformation in the soil, which affects its availability for the plants, it is subject to soil-plant system losses, causing damage to the environment [6] [25].

Although part of the organic nitrogen in the soil is mineralized by microbial activity, in the majority of the soils, this amount is not enough to meet the demand of this nutrient in demanding crops. Thus, organic nitrogen existing in the soil is slowly released throughout the year, and the demanding rate of the crops is higher in the early stages of growth, requiring larger amounts of this nutrient [5] [18]. The use of other sources of nitrogen besides soil is therefore necessary. 
Organic nitrogen from manure is manly found in the proteins, amino acids, urea and amine; and in lower concentrations as ions such as ammonium, nitrate and nitrite. The content and forms of $\mathrm{N}$ in the manure depends on the stage of decomposition, storage and temperature conditions. Nitrogen transformations of manure in the soil are carried out by heterotrophic microorganisms, which decompose organic-N to produce amine and transform it into $\mathrm{NH}_{4}{ }^{+}$. In the presence of atmospheric air, ion $\mathrm{NH}_{4}{ }^{+}$is oxidized to $\mathrm{NO}^{2-}$ by Nitrosomonas, and then oxidized to $\mathrm{NO}^{3-}$ by nitrobacteria [26]. As plants preferentially absorb inorganic forms of $\mathrm{N}, \mathrm{N}$ availability to the plants is gradual. Therefore, manure needs to be applied to the soil in advance to coincide with the largest availability of $\mathrm{N}$ in order to fulfill the greater needs of the plant. It is noteworthy that there is a possibility of inorganic nitrogen losses as nitrate through leaching, and ammonium through volatilization, mainly when manure is applied in alkali, dry and hot soil.

According to [27], alternative sources of nitrogen such as animal waste (slurry, urine, etc.), manure, green fertilizer, vegetable compost and agricultural industry residues, are having special importance in recent years due to the high costs of fertilizers having limited scope to small farmers, and as a support to sustainable agriculture.

Manure has a direct and indirect effect on crop production according to [28]. The direct effect depends on the amount of nutrients in the soil composition, and the amount of mineral fertilizers that may be replaced by its use. The indirect effect of manure is related to its beneficial action on physical and chemical properties of the soil, and the intensification of microbial and enzymatic activities.

Cattle may eliminate $40 \%$ to $50 \%$ of their organic matter intake through feces, containing means of $75 \%$ nitrogen, $80 \%$ phosphorus and $85 \%$ potassium, and because of this, reusing manure recycles more than half of the total nutrient content originally ingested. For plants utilizing the nutrients contained in the manure, the transformation process of organic molecules through biological decomposition is required. Mineralization is the transformation of an element from organic compost to a simple mineral that can be useful for the plants because it only absorbs the nutrients in the mineral form [12] [29].

According to [28], organic fertilizer presents, in general, a greater residual effect on the soil than mineral fertilizers. This can be explained by the slow mineralization of organic composts making it available for longer. In this way, nutrients are less subject to the chemical reactions of the soil, the opposite of mineral fertilizers. In the specific case of nitrogen, organic fertilizer tends to supply it for longer as a consequence of the slow mineralization of organic composts, whereas from the mineral source the nitrogen is easily lost through leaching and volatilization.

In this context, [30] revised the literature and reported that some nutrients of organic material are available more quickly than others, because organic fractions have different resistance to decomposition. The majority of nitrogenous fractions decompose quickly and their mineralization rates change by material nature, soil type, temperature and microbial activity.

It is noteworthy that one of the limitations of using animal manure in crops or pastures is the low concentration of, and the variety of nutrients, which are necessary when applying higher amounts of mineral fertilizers in order to supply the nutritional requirements from the plants. Normally, nitrogen is the main element considered in determining dosages of manure to be applied, but if used in excess it can cause nitrate accumulation in the plants or in the water sources [1] [6] [31]. The availability rate of nitrogen in pig manure for the first crop is 0.8 [32].

\subsection{Types of Nitrogen Losses}

Factors which cause losses of ammonia by volatilization are rain intensity, amount applied, method of application and dry matter content [1]. [33] observed ammonia losses by volatilization between 24 to 48 hours post-application of fresh manure. [34] observed the effect of wind speed, temperature and water vapor over the loss of ammonia in a six-day period. The authors reported that when the temperature was close to zero, ammonia losses were low and it was concluded that calculating the losses was difficult because the mineralization process occurred immediately following the storage. [7], however, reported that pig manure spread on soil surface resulted in nitrogen losses by volatilization between $24 \%$ to $80 \%$. Similar losses were observed by other researchers [1] [10] [35]-[37].

\subsection{Strategies to Decrease Nitrogen Losses on Manure}

Large amounts of nitrogen applied organically can be lost through ammonia volatilization, denitrification or leach- 
ing, however the incorporation into soil applications diminishes the magnitude of the phenomenon [23] [30]. The losses are always larger in the early stages, subsequent to material application and promote a decrease in the potential supply of nitrogen, which can limit vegetation growth, mainly if it is applied well before planting.

In a study to reduce nitrogen losses via slurry, [35] observed that decreasing the $\mathrm{pH}$ from 7.5 to 6.0 through sulfuric acid reduced ammonia volatilization by means of $82 \%$ and $74 \%$ for pig and cattle manure, respectively. When $\mathrm{pH}$ was decreased to 5.5 , volatilization was found to have decreased by 88 and $95 \%$ for pigs and cattle, respectively. Therefore, it was concluded that at least $80 \%$ of ammonia losses in pigs and cattle manure could be prevented through acidification at $\mathrm{pH}$ values of 6.0 and 5.5. Similarly, [33] worked with calcium chloride in order to reduce losses in fresh poultry manure and observed that the concentration of $36 \mathrm{mg} / \mathrm{kg}$ of Ca (based on dry weight), reduced ammonia losses by $73 \%$ and total losses of other forms of nitrogen by $37 \%$. The use of calcium chloride on manure in an anaerobic storage system, however, only decreased volatilization loss by $8 \%$. The author also reported that the use of calcium chloride did not affect urea hydrolysis or nitrogen mineralization.

When evaluating nitrogen availability of cattle manure from nature or biodigestion effluent, [38] reported that, for the application of cattle manure, which was partially stabilized prior to addition to the soil, the immobilization and nitrogen losses by nitrification were lower compared to the application of natural cattle manure, even when high dosages were used. Therefore, the same authors concluded that parceling doses, incorporation before sowing, composting and fermenting manure in digesters or dunghills, are measures that can reduce nitrogen losses, increasing its availability to the crop. [39] observed the same advantages of biodigestive cattle manure in relation to the availability of nitrogen for the plant.

It is noteworthy that there is little information about the efficiency of manure as fertilizer. [31] recommended the use of $488 \mathrm{~kg} \cdot \mathrm{N} / \mathrm{ha}$ of pig manure for fertilizing grass (Cynodon dactylon), assuming a loss of $50 \%$ nitrogen by volatilization. It was emphasized that nitrogen losses by volatilization and denitrification vary by the application method, the type and humidity of the soil, temperature and the interaction of all the factors. In general, the recommended dose depends on the absorption potential of the species [1] [10].

Other strategies to decrease nitrogen losses were suggested by many authors, such as the application of the slurry at times of milder temperature (early morning or end of the day); the use of slurry (preferably on established vegetation) and the analysis of $\mathrm{pH}$ prior to application [10] [33] [34] [40].

\subsection{General Aspects of Organic Matter}

Organic matter has difficult decomposition and can be used to provide humus. Legume foliage is rich in protein and decomposes easily, while grass roots are rich in lignin and are therefore more difficult to decompose, which can provide humus when decomposition occurs in semi-anaerobic environments. Leaves and roots provide different fermentation products because of the higher content of lignin in the roots. While the leaves have lignin contents between $5.5 \%$ and $9.0 \%$, in the roots it increases to $20 \%$ in some cases for grasses [41].

Substances which decompose easier are mineralized first and generally rapidly decompose to carbon dioxide, water and minerals [42]. Green manure made using legumes have lower probability to remain in the soil longer than six weeks and therefore is hardly considered as an enrichment source of organic matter in the soil, but as a form of nitrogen fertilization once its nitrogen content is high.

Forage grass, on the other hand, can develop its roots freely and is the safest way to enrich the soil with humic substances. Decomposition speed depends not only on the ventilation and the number and activity of bacteria, but on the material composition and its C: $\mathrm{N}$ ratio. Starch and protein are the first substances to decompose, followed by cellulose. Lignin has slower decomposition because of its complex structure [41]. [30] [43] reported that material with higher $\mathrm{C}: \mathrm{N}$ ratios allow for more extensive aggregation, due to their slower decomposition and higher production of intermediate compounds. The same author registered that the contribution of organic residues on the improvement of organic matter content is related to three factors: amount of residue incorporated, frequency of the practice and the material composition.

[44] presenting data adapted from [45] defined the distribution of carbon pools in the agriculture system into four groups: 1) living vegetative biomass, 2) vegetable, root and exudates residues, 3) unprotected organic matter and 4) protected organic matter. The ones referring to living biomass and residues have a residence time of approximately one quarter of a year; and act by protecting the soil from erosion, recycling nutrients and as a source of food to biological activity. The pool referring to unprotected organic matter can be divided into two 
groups; one of them refers to microbial biomass existent in the soil, which has a short residence time and acts on vegetative residue decomposition and temporary aggregation as a nutrient source. The other group refers to labile organic matter, which has a residence time of 2 to 5 years and acts as a temporary aggregating agent, a source of nutrients to plants, a microbial energy source and influences soil cation exchange capacity (CEC). The last pool is also divided into two groups: structurally protected organic matter and colloid protected organic matter. Both groups act as permanent aggregation agents and act on soil CEC, with a residence time estimated at 1000 years.

In a more simplified approach to soil organic matter, crop residues in an advanced stage of decomposition, microbial biomass, root and the most stable fraction called humus can be included ${ }^{7}$. It can be therefore inferred that the carbon present in these fractions does not mineralize or stabilize at the same speed and can be accepted that crop residues gradually decompose, forming stable molecules by a variety of physical, chemical, microbial and soil fauna processes. According to [46], stabilization is a decrease of the potential to lose organic matter in the soil by respiration, erosion or leaching. In this case there is a type of material produced which resists posterior transformations. The stabilization process can start before plant tissue reaches the soil or before its death.

\subsection{Mineral Composition of Slurry and Its Influence on Soil-Plant-Water}

Other factors can be observed in the use of slurry on agricultural soil. In this context, [47] mentioned that pig manure, due to mineral supplementation provided to the animals, contained considerable amounts of heavy metals as $\mathrm{Cu}, \mathrm{Zn}$ and Fe. These elements act as nutrients in certain amounts, but in higher doses can be toxic to the plants. This can be seen in [30] study, which evaluated the use of food enriched with $\mathrm{Zn}$ in pigs and observed that the slurry increased zinc content in the soil to values greater than zinc oxide, and resulted in a residual effect in corn crops.

In addition to nitrogen, manure presents considerable amounts of $\mathrm{P}, \mathrm{K}, \mathrm{Ca}, \mathrm{Mg}, \mathrm{S}$ and micronutrients. It is noteworthy that from the point of view of plant nutrition, not only is the content of total nutrients of the manure important, but also the nutrients available in the moment and the amount required by the crop [48].

The nutritional requirements of an intensively cultured crop are rarely met in a balanced way when only organic material is used. This happens due to the concentration of $\mathrm{N}_{2} \mathrm{P}_{2} \mathrm{O}_{5}$ and $\mathrm{K}_{2} \mathrm{O}$, which are normally different from the required ones. Therefore, in addition to the plant requirements, the concentration of the nutrients in the materials, the humidity and the conversion rates must be considered [49] [50].

For [51], the accumulation of $\mathrm{P}$ and $\mathrm{K}$ through the use of animal manure for long periods can cause nutritional imbalances. The effect of excessive accumulation of $\mathrm{P}$ available in the soil produces deficiencies of $\mathrm{Zn}$ while the excess of $\mathrm{K}$ causes $\mathrm{Mg}$ deficiencies. The accumulation of $\mathrm{K}$ and $\mathrm{Na}$ in exchangeable form in the soil cause breakdown and decrease the structural stability of the soil. [52] also observed an increase in the sum of base due to potassium increases, and in the reduction of $\mathrm{pH}$ which caused the reduction in base saturation and the increase in exchangeable aluminum. These undesirable effects occur after many decades and require time and commitment to be corrected.

According to [49], the organic material (solid or liquid) incorporated in the soil increased the efficiency of phosphorus use, due to the low mobility of this element in the soil and also prevented nitrogen losses by volatilization. However, the incorporation of organic matter in the soil accelerates its decomposition, which is not always desirable. It should also be applied after the establishment of a root system and not at planting time, aiming to reduce nitrogen losses by leaching. Part of the nitrogen of these materials is in the mineral form, and behaves similarly to nitrogen contained in traditional fertilizers.

It is noteworthy that for each ton of non-uses slurry, about $10 \mathrm{~kg}$ of NPK are lost. Unfortunately, information and research in Brazil about the impact of pig and cattle manure on the environment are poorly represented; this could subsidize the use of these materials in annual and perennial crop pastures [53].

Another aspect to be mentioned is the need for more scientific information of physical, chemical and biological effects of manure in soil, plants and water. Performing initial experiments on this, [54] observed the effect of pig manure on physical characteristics of the soil in a conventional crop system. The authors registered significant changes in the reduction of water infiltration which can consequently exacerbate erosion problems, mainly in areas with other favorable conditions for water runoff. The reduction of the infiltration is thus assumed as socio-economically and ecologically important because it involves issues related to environmental contamination, showing the need for integrated studies to contribute to a common goal. There are few authors who have shown 
significant relations that involve the effects of application of manure to the physical, chemical and biological soil characteristics [50] [55]-[60]. [50] characterized the effect of lipids on the physical characteristics of soil, reporting positive effects of its presence to aggregation and stability and a negative effect on water retention.

In Table 1, the chemical composition of cattle and pig manure according to many authors can be observed.

\subsection{Use of Manure as Forage Fertilizer}

In the production of grass for silage purposes, [61] obtained maximum benefits of nutrients as a result of the application of pig manure by experimental results. The amounts applied were 68,73 and $112 \mathrm{~m}^{3} / \mathrm{ha}$, in two applications, as compared to the chemical fertilizer. This allowed the $\mathrm{N}$ and $\mathrm{P}$ requirements to be met, although $\mathrm{K}$ needed to be supplemented; using cattle manure it was necessary to supplement $\mathrm{N}$ and $\mathrm{P}$. Dry matter production obtained in the experiment did not show significant differences between the animal slurry and the chemical fertilizer, and between the lower and higher amounts of fertilizer applied. This shows the importance of rational reuse of animal manure, ensuring higher yields, lower costs and conditions for environmental protection.

[39] compared fermented manure to biodigested slurry for millet crop and verified that fermented manure promoted the increase of $\mathrm{C}-\mathrm{CO}_{2}$ release compared to the control, which was three times higher than the effect of biogidested slurry. The nutrient content of fermented manure from cattle was however lower than that of the biodigested slurry, for almost all nutrients analyzed.

Crops such as maize have increased productions as reported by [62], who observed significant effects on grain yield maize using pig manure. A maximum production of $8766 \mathrm{~kg} / \mathrm{ha}$ was obtained at the dose $0149 \mathrm{~m}^{3} / \mathrm{ha}$, approximately a $44 \%$ greater increase compared to control. A similar result was observed by [63] which suggested the use of a yearly dose of $44 \mathrm{~T}$ of cattle manure per ha of maize crops.

Slurry also stimulates microbial activity, promoting a higher mineralization of organic matter and resulting in a rapid soil cover by vegetation, which has great importance in the recovery of degraded areas [64]. The addition of pig slurry at doses of 400, 600 and $800 \mathrm{~kg} / \mathrm{ha}$ of nitrogen stimulated a rapid increase of the microbial population in the soil. The survival of fecal bacteria in the soil was less than two weeks, returning to normal levels after this period [57]. These results are explained by some authors as a result of increased competition and antagonistic effects of other microorganisms in the soil, and by poor environmental conditions for fecal microbial survival.

[4] used $20 \mathrm{~m}^{3}$ of pig slurry and obtained productions of star grass 2-IPEAME and Hermarthria IAPAR of 55 and $76 \%$, respectively, compared to the control group. According to [65], the observations from the use of pig manure for pasture fertilization have shown greater yield production of beef and dairy cattle, with productivity reaching $1500 \mathrm{~kg} / \mathrm{ha} / \mathrm{year}$, with a capacity of 6.5 to 7.5 animal units. Beneficial effects on fertility and water retention in the soil were also observed after the second year of application without considering the increase in bi-

\section{Table 1. Mean composition of animal manure according to different authors.}

\begin{tabular}{|c|c|c|c|c|c|c|c|c|}
\hline \multirow{2}{*}{ Source } & $\mathrm{Ca}$ & Mg & $\mathbf{P}$ & $\mathbf{K}$ & DM & $\mathbf{N}$ & pH & \multirow{2}{*}{ Authors } \\
\hline & & \multicolumn{3}{|c|}{$\mathrm{g} / \mathrm{kg}$} & \multicolumn{3}{|c|}{$\mathrm{g} / \mathrm{L}$} & \\
\hline Cattle & 9.5 & 3.8 & 2.1 & 7.8 & 8.5 & 3.6 & 7.2 & [56] \\
\hline Cattle & 3.1 & 1.6 & 3.3 & 11.1 & 15.7 & 2 & 5.7 & [28] \\
\hline Cattle & - & - & 2.2 & 6.4 & 8.7 & 5.6 & 7.6 & [36] \\
\hline Cattle & - & - & 3.1 & 13.2 & 4.0 & 4.0 & 6.7 & [66] \\
\hline Cattle & - & - & - & - & 5.9 & 5.2 & 7.5 & [34] \\
\hline Pig & 4.8 & 1.5 & 5.0 & 16.3 & - & 8.4 & - & [48] \\
\hline Pig & 2.9 & 3.7 & 2.9 & 3.7 & - & 4.0 & - & [57] \\
\hline Cattle & 19.8 & 4.6 & 3.8 & 8.3 & - & 4.9 & - & [58] \\
\hline Cattle & 8.50 & 2.97 & 2.38 & 19.65 & 4.93 & 4.87 & 7.60 & [59] \\
\hline Pig & 1.00 & 0.96 & 3.64 & 2.64 & - & 3.23 & - & [60] \\
\hline
\end{tabular}


ological activity of the soil. Similarly, [58] in an experiment with Tanzania grass (Panicum maximum) obtained yields of dry matter production from aerial components five times higher than that of the control when $180 \mathrm{~kg}$ of $\mathrm{N} / \mathrm{ha}$ was used as cattle manure.

While working with slurry, [60] applied doses of 0,20 and $40 \mathrm{~m}^{3} /$ ha every 45 or 60 days in a nature pasture and observed that the maximal addition of slurry increased the content of $\mathrm{P}, \mathrm{Ca}$ and $\mathrm{Mg}$, and decreased aluminum saturation in the soil. However, in the same experiment, with regards to nitrogen, [66] showed that only 53 and $35 \%$ of nitrogen applied through pig slurry, at doses of 20 and $40 \mathrm{~m}^{3} / \mathrm{ha}$, respectively, was exported to the dry matter of the nature pasture. Therefore, [3] concluded that doses of pig slurry for maize production, both in the Cerrado region and in traditional cropping, vary from 45 to $90 \mathrm{~m}^{3} / \mathrm{ha}$; and in direct seeding from 50 to 100 $\mathrm{m}^{3} / \mathrm{ha}$. For dry matter production in intensive pasture, the most efficient dose was between 150 to $180 \mathrm{~m}^{3} / \mathrm{ha}$ of pig slurry per year, divided into 5 or 6 applications.

In the study of [67], evaluating the effect of cattle slurry as a nitrogen source in four doses $(0,60,120$ and 180 $\mathrm{kg} / \mathrm{ha}$ ), an increase of dry matter production and a decrease of neutral detergent fiber were observed in addition to an increase of crude protein and acid detergent fiber at the highest dose over 84 days of collection of Tanzania grass. The authors registered that nitrogen in the form of slurry promoted the increased production of dry matter and higher contents of nitrogen in the roots. Concomitantly, [68] tested doses of 0,150 and $300 \mathrm{~kg} / \mathrm{ha}$ of cattle slurry as a nitrogen source and observed that the application of slurry increased the contents of $\mathrm{P}, \mathrm{K}, \mathrm{Mg}$ and the $\mathrm{pH}$ of the soil. [69] observed an influence of 0,75 and $150 \mathrm{~kg} / \mathrm{ha}$ doses of $\mathrm{N}$ in the form of cattle slurry on the concentrations of K, N and dry matter for coast-cross, Tifton 85, suázi and transvala grasses. The authors did not observe any significant difference between the grasses for the content of $\mathrm{N}$ or $\mathrm{K}$, or dry matter production. However, annual ryegrass (Lolium multiflorum) crops obtained increases of dry matter from 11.5 to $14.7 \mathrm{~T} / \mathrm{ha}$ and of crude protein from 1.89 to $3.39 \mathrm{~T} / \mathrm{ha}$, when $50 \mathrm{~T} /$ ha of cattle slurry was applied.

For Bermuda grass (Cynodon dactylon) fertilized with pig slurry, [31] observed that the concentration of crude protein increased with the application of pig slurry at the equivalent nitrogen dose of $846 \mathrm{~kg} / \mathrm{ha}$. [70] applied pig slurry at doses of $0,50,150$ and $200 \mathrm{~m}^{3} /$ ha/year on this grass species and observed that the minimal benefits of nitrogen in the soil were obtained at a superior dose of $100 \mathrm{~m}^{3} / \mathrm{ha} /$ year during the summer.

[71] evaluated the effect of fertilization with pig slurry in Brachiaria brizantha by a variety of treatments and observed better results of chemical composition (crude protein, neutral detergent fiber, acid detergent fiber and dry matter digestibility) occurring with the application of $180 \mathrm{~m}^{3} / \mathrm{ha} /$ year, in natural or fermented form during the wet season. For dry matter production and tilling density the same behavior was observed, emphasizing the dose of $180 \mathrm{~m}^{3} / \mathrm{ha} /$ year [72]. The authors concluded that this residue can successfully replace chemical nitrogen fertilizer. Similarly, it was validated by [73], who concluded that the application of $180 \mathrm{~m}^{3} / \mathrm{ha} /$ year of pig slurry, whether fermented or in nature, that this input enables the obtaining of high yields of dry matter production, similar to mineral fertilizer.

Noting the importance of this input, not only on aerial plant biomass, but also in root biomass, [74] tested doses of cattle manure as a nitrogen source and found higher root mass at a dose of $300 \mathrm{~kg}$ of $\mathrm{N}$ for coast-cross grass and $150 \mathrm{~kg}$ of $\mathrm{N}$ for Tifton 85 .

[75] evaluated dry matter production of Brachiaria brizantha cv. Marandu in Mato Grosso and did not observe differences between the seasons (wet and dry) and its effects on dry matter production when $100 \mathrm{~m}^{3} / \mathrm{ha} / \mathrm{year}$ was used. The authors concluded that the effect of cattle manure application was the main factor in attenuating the effect of hydric stress and then maintaining pasture production. Concomitantly, [76] in an experiment using elephant grass (Pennisetum purpureum) fertilized with between 30 and $70 \%$ pig slurry added to cattle manure, highlighted an uniform forage distribution among the seasons of the year.

[1] concluded that the application of pig slurry is a valid alternative to increase production in Tifton 85 pastures. The dose of $30 \mathrm{~m}^{3} / \mathrm{ha}$ was suggested as reference value, after cutting or grazing, as the efficiency of the fertilizer is affected by environmental conditions. Therefore, the application should be carried out when the pasture is growing vigorously, where nutrient absorption is higher. In southern Brazil the application period should be restricted from early spring until mid-summer.

\section{Multivariate Statistical Analysis in Research on Use of Manure}

One way to study the productive potential of forage is through the response obtained from different levels of fertilization. Experiments in this method are carried out in pots or in the field, and samples from different parts of 
the plants are collected for full analysis of the grass [77]. However, the analysis, does not routinely consider the complexity existing between the variables studied. This is an error that is particularly important, predominantly in organic fertilization, because the response at the level of fertilization which provides all essential nutrients required by the plant, needs to consider morphological and productive characteristics of the cultivar as a whole and not from isolated aspects. For example, cultivar " $\mathrm{A}$ " can have a higher content of some nutrients and lower content for others in comparison to cultivar "B". In the literature these cultivars are compared for each characteristic individually and the conclusions are direct for each characteristic.

For the understanding of the complex correlation between forage plants (nutritional value, morphogenetic and structural characteristics, dry matter production, etc.) a multivariate procedure known as Principal Component can be used. Principal components are linear combinations of original variables and are estimated in a way that the first principal component explains the largest percentage of total variance, the second principal component explains the second largest percentage and successively until all the variance can be explained [78]. Each original variable is associated to a principal component by a weighting called eigenvectors, whose respective absolute values determine the importance of the characteristic for each principal component, with the signs (positive or negative) indicating the relation existent between the characteristics (equal signs indicating positive correlation, and different signs indicating negative correlation). This technique therefore enables the attempt to comprehend the network of existing correlations among the numerous characteristics of forage plants. To obtain more specific conclusions about the effect of fertilization in pasture, it is necessary to use other procedures that simultaneously analyze multiple characteristics.

Among these, discriminant analysis is related to either efficient separation or the discrimination of two or more groups using for linear discriminant functions [79]. According to [80], discriminant analysis is based on a dispersion matrix of original variables and on the estimation of Mahalanobis distance for group formation, and consequently, to classify the variables into the groups formed. In theory, this analysis enables the comparison of the treatments would then support a set of characteristics instead of isolated variables, which means that the additive effect of the variables in study could be evaluated.

In this context, [72] and [74], evaluating species from the Digitaria and Cynodon genera fertilized with cattle manure as a nitrogen source by principal component analysis, registered that the most important variables that should be considered in an experiment about the effects of nitrogen application via slurry on aerial components of the grass are calcium, nitrogen, phosphorus, potassium and dry matter. For root production the principal components found were dry matter and magnesium.

Using discriminant analysis, [81] registered that for Transvala cultivars, Ca content was the most important nutrient in aerial components, followed by dry matter production, while $\mathrm{P}$ and $\mathrm{N}$ content were the most important in the roots, followed by Mg. For Tifton 85 cultivars, a fairly similar order to Transvala cultivars was observed, with only the exchange of position between $\mathrm{Mg}$ and $\mathrm{N}$ content. The authors concluded that discriminant analysis based on the studied variables showed that cultivars, although belonging to the same genera, behave differently according to the macronutrient content and production of dry matter of both aerial components and roots. Therefore, studies that include principal components analysis and/or discriminant analysis, in their experimental protocols, enable the understanding of the association between the variables and thus the segregation of the grasses according to their behavior, which means that it goes beyond the genera for grouping forage species.

In an experiment aiming to evaluate Tanzania grass fertilized with slurry by a multivariate procedure of discriminant analysis and principal component analysis, [82] concluded that principal component analysis reduced the number of original variables from 15 to 6 principal components, and that the most important variables in terms of variation were calcium in the roots, potassium in the leaves, potassium in the plant, magnesium in the leaves, phosphorous in the leaves and phosphorus in the roots. It is recommended that in further studies evaluating the effects of slurry fertilization and mineral composition of the plants, multivariate procedures should be conducted to obtain more complete results. It is however, noteworthy that such studies should be grounded in larger samples because many non-controlled factors in grass experiments can compromise the results.

\section{Conclusions}

Slurry from pig and cattle can be used as efficient and safe fertilizers in forage production, considering the doses of reposition of nutrients used by the crop.

The use of slurry as a nitrogen source is an interesting alternative, considering the high costs of industrial input and the need to use renewable material which minimize environmental impacts. 
Slurry positively affects the productivity and nutrient contents of forage plants, improving the efficiency of production systems.

Further studies are necessary to establish forms of use and suitable amounts of sourced nitrogen and other nutrients, in order to decrease losses and avoid environmental contamination.

Fertilization with manure should involve assumptions that lead to increasing the efficiency of application, costs and doses, considering that the doses for pig manure can range from 30 to $180 \mathrm{~m}^{3} / \mathrm{h}$ a for conventional planting, and that cattle manure can range from 25 to $100 \mathrm{~m}^{3} / \mathrm{ha}$, or from 50 to $300 \mathrm{~kg}$ of $\mathrm{N}$, depending on the handling system.

\section{Acknowledgements}

Thanks to National Council for Scientific and Technological Development.

\section{References}

[1] Scheffer-Basso, S.M., Scherer, C.V. and Ellwanger, M.F. (2008) Response to Fertilization Perennial Pastures with Pig Slurry: Natural Pasture. Journal of Animal Science, 37, 221-227.

[2] Schroder, J.J. and Stevens, R.J. (2000) Does the Crop or the Soil Indicate How to Save Nitrogen in Maize Production? Reviewing the State of the Art. Field Crops Research, 62, 151-164. http://dx.doi.org/10.1016/S0378-4290(00)00072-1

[3] Konzen, E.A. (2003) Utilization of Pig Slurry for Fertilization and Fertigation in Major Crops. Technical Circular. Embrapa-MG, Sete Lagoas, 11.

[4] Oliveira, E., Postiglioni, S.R. and Sá, J.P.G. (1997) Effect of Organic and Mineral Fertilization on Yield and Cynodon altissima Hermarthria nlemfuensis. XXXIV Annual Meeting of the Brazilian Society of Animal Science 1997, Juiz de Fora, MG. In: Proceedings, Juiz de Fora, 145-147.

[5] Schroder, J.J. (2005) Revisiting the Agronomic Benefits of Manure: A Correct Assessment and Exploitation of Its Fertilizer Value Spares the Environment. Bioresource Technology, 92, 253-261. http://dx.doi.org/10.1016/j.biortech.2004.05.015

[6] Subramanian, S., Sivarajan, M. and Saravanapriya, S. (2010) Chemical Changes during Vermicomposting of Sago Industry Solid Wastes. Jounal of Hazardous Materials, 179, 318-322. http://dx.doi.org/10.1016/j.jhazmat.2010.03.007

[7] Moset, V., Cambra-López, M. and Møller, H.B. (2012) The Inhibiting Effect of Sulfate on Thermophilic Anaerobic Digestion of Cattle Manure. Transactions of the ASABE, 55, 220-230. http://dx.doi.org/10.13031/2013.42499

[8] Barcellos, L.A.R. (1991) Evaluation of the Fertilizing Potential of the Liquid Cattle Manure. M.Sc. Dissertation, Federal University of Santa Maria, Rio Grande do Sul, 108 p.

[9] Schroder, J.J., Jansen, A.G. and Hilhorst, G.J. (2005) Long Term Nitrogen Fertilizer Value of Cattle Slurry. Soil Use and Management, 21, 196-204.

[10] Bohutskyi, P. and Bouwer, E. (2013) Biogas Production from Algae and Cyanobacteria through Anaerobic Digestion: A Review, Analysis, and Research Needs. Advanced Biofuels and Bioproducts, 20, 873-975. http://dx.doi.org/10.1007/978-1-4614-3348-4_36

[11] Souza, W.J.O. and Melo, W.J. (2000) Nitrogen Contents in Soil and Organic Matter Fractions under Different Production Systems of Corn. Brazilian Journal of Soil Science, 24, 885-896.

[12] Moller, K. (2010) Effects of Organic Wastes Digestion for Biogas Production on Mineral Nutrient Availability of Biogas Effluents. Nutrient Cycling in Agroecosystems, 87, 395-413. http://dx.doi.org/10.1007/s10705-010-9346-8

[13] Campos, A.T., Ferreira, W.A., Paccola, A.A. and Lucas, J. (2002) Aerobic Biological Treatment and Recycling of Waste from Cattle under Intensive System of Milk Production. Agrotecnic Science, 26, 426-438.

[14] Queiroz, F.M., Matos, A.T. and Pereira, O.G. (2004) Soil Chemical Properties and Nutrient Uptake by Forage Grasses on the Ramps of the Swine Wastewater. Journal of Engineering in Agriculture, 12, 77-90.

[15] Matos, A.T. (2004) Treatment and Utilization of Agricultural Solid Waste. AEAGRI, Viçosa, 139 p.

[16] Matos, A.T. (2004) Use of Waste from Swine and Cattle Feedlot Manure on Forage. Proceedings of the Symposium on Strategic Management of Grassland, Viçosa, 2004, 25-70.

[17] Schroder, J.J., Van Schooten, H., Bruinenberg, M. and Van Dijk, W. (2005) De stikstofwerkingscoëfficiënt van organische mest op maïsland; Berkendijk 1988-2002. Rapport 101, PRI, Wageningen, 19 p. (In Dutch)

[18] Sutaryo, S., Ward, A. and Moller, H.B. (2013) Anaerobic Digestion of Acidified Slurry Fractions Derived from Different Solid-Liquid Separation Methods. Bioresource Technology, 130, 485-495. http://dx.doi.org/10.1016/j.biortech.2012.12.037 
[19] Almeida, L.A. (2000) Certification of Organic Milk and Dairyproducts. Proceedings Symposium on Sustainability of Dairy Cattle in Brazil, Juiz de Fora, 2000, 166-177.

[20] Fonseca, M.F. (2000) Social Construction of the Organic Food Market, Strategies of Different Actors in the Production and Marketing of Fruits and Vegetables in Nature Network in the State of Rio de Janeiro. CPDA/UFRRJ, Rio de Janeiro, 210.

[21] Aroeira, L. (2000) Organic Products: An Expanding Market. Proceedings Symposium on Sustainability of Dairy Cattle in Brazil, Juiz de Fora, 2001, 188-199.

[22] Schroder, J.J. and Stevens, R.J. (2004) Optimizing N Additions: Can We Integrate Fertilizer and Manure Use. In: Hatch, D.J., Chadwick, D.R., Jarvis, S.C. and Roker, J.A., Eds., Controlling Nitrogen Flows and Losses, Wageningen Pers, Wageningen, 586-593.

[23] Tognetti, C., Mazzarino, M.J. and Laos, F. (2008) Compost of Municipal Organic Waste: Effects of Different Management Practices on Degradability and Nutrient Release Capacity. Soil Biology and Biochemistry, 40, 2290-2296. http://dx.doi.org/10.1016/j.soilbio.2008.05.006

[24] Corsi, M. (1986) Pastures with High Productivity. In: Proceedings of the Symposium on Management of Grassland, FEALQ, Piracicaba, 499-512.

[25] Zapata, F. (2000) Fuentes alternativas para la fertilización nitrogenada de cultivos anuales. In: Zapata, F., Ed., Manejo eficiente e la fertilización nitrogenada de cultivos anuales em América, UFRGS, Porto Alegre, 1986, 378 p.

[26] Tiquia, S.M. (2005) Microbiological Parameters as Indicators of Compost Maturity. Journal of Applied Microbiology, 99, 816-828. http://dx.doi.org/10.1111/j.1365-2672.2005.02673.x

[27] Urquiaga, S. and Zapata, F. (2000) Fuentes Alternatives to Nitrogen Fertilization of Her Anuales Crops. In: Urquiaga, S. and Zapata, F., Eds., Efficient Management and Nitrogen Fertilization of Her Anuales Crops in Latin America and Caribbean, Genesis, Porto alegre and Embrapa Agrobiologia, Rio de Janeiro, 57-76.

[28] Scherer, E.E., Castilhos, E.G. and Aita, C. (1984) Effect of Fertilization with Pig Manure, Nitrogen and Phosphorus in Corn. EMPASC, Florianópolis, 26 p.

[29] Tognetti, C., Mazzarino, M.J. and Laos, F. (2007) Improving the Quality of Municipal Organic Waste Compost. Bioresource Technology, 98, 1067-1076. http://dx.doi.org/10.1016/j.biortech.2006.04.025

[30] Ernani, P.R., Bittencourt, F. and Valmorbida, J. (2001) Influence of Successive Additions of Zinc, in the Form of Pig Manure or Oxide in Dry Matter Yield of Maize. Brazilian Journal of Soil Science, 35, 905-911.

[31] Rogers, J.R., Harvey, R.W. and Poore, M.H. (1996) Application of Nitrogen from Swine Lagoon Effluent to Bermudagrass Pastures: Seasonal Changes in Forage Nitrogenous Constituents and Effects of Energy and Escape Protein Supplementation on Beef Cattle Performance. Journal of Animal Science, 74, 1126-1133.

[32] Brazilian Society of Soil (2004) Manual Fertilization and Liming in the States of Rio Grande do Sul and Santa Catarina. Commission of Chemistry and Fertility of Soils, Rio Grande do Sul, 400 p.

[33] Witter, E. (1991) Use of $\mathrm{CaCl}_{2}$ to Decrease Ammonia Volatilization after Application of Fresh and Anaerobic Chicken Slurry to Soil. Journal of Soil Science, 42, 369-380. http://dx.doi.org/10.1111/j.1365-2389.1991.tb00415.x

[34] Sommer, S.G., Hutchings, N.E. and Schjorring, J.K. (1991) Effects of Temperature, Wind Speed and Air Humidity on Ammonia Volatilization from Surface Applied Cattle Slurry. Journal of Agriculture Science, 117, 91-100. http://dx.doi.org/10.1017/S0021859600079016

[35] Stevens, R.J., Laughlin, R.J. and Frost, J.P. (1989) Effect of Acidification with Sulphuric Acid on the Volatilization of Ammonia from Cow and Pig Slurries. Journal of Agriculture Science, 113, 389-395. http://dx.doi.org/10.1017/S0021859600070106

[36] Frost, J.P., Stevens, R.J. and Laughlin, R.J. (1990) Effect of Separation and Acidification of Cattle Slurry on Ammonia Volatilization and on the Efficiency of Slurry Nitrogen for Herbage Production. Journal of Agriculture Science, 115, 49-56. http://dx.doi.org/10.1017/S0021859600073901

[37] Stevens, R.J. and Laughlin, R.J. (2002) Cattle Slurry Applied before Fertilizer Nitrate Lowers Nitrous Oxide and Dinitrogen Emissions. Soil Science Society of America Journal, 66, 647-652. http://dx.doi.org/10.2136/sssaj2002.6470

[38] Aita, C. and Fries, M.R. (1990) Nitrogen Availability with Application of Cattle Manure and Biodigester Effluent on a Red-Yellow Podzolic. Journal of Rural Science, 20, 125-135.

[39] Sampaio, E.V.S.B., Salcedo, L.H. and Alves, G.D. (1985) Comparison of Aged Manure and Biodigested Manure as a Nutrient Source for the Millet. Brazilian Journal of Soil Science, 20, 27-31.

[40] Sommer, S.G., Hutchings, N.E. and Schjorring, J.K. (1993) Ammonia Volatilization during Storage of Cattle and Pig Slurry: Effect of Surface Cover. Journal of Agriculture Science, 121, 63-71. http://dx.doi.org/10.1017/S0021859600076802

[41] Primavesi, A. (1982) The Ecological Soil Management: Agriculture in Tropical Regions. 5th Edition, Nobel, São Paulo, 
$54 \mathrm{p}$.

[42] Moller, K., (2010) Effects of Different Manuring Systems with and without Biogas Digestion on Nitrogen Cycle and Crop Yield in Mixed Organic Dairy Farming Systems. Nutrient Cycling in Agroecosystems, 82, 209-232. http://dx.doi.org/10.1007/s10705-008-9196-9

[43] Muzzili, O. (1986) A Green Manure as an Alternative for Improving Soil Fertility and Rational Use of Fertilizers. IAPAR, Londrina, $14 \mathrm{p}$.

[44] Mielniczuk, J. (1999) Organic Matter and Sustainability of Agricultural Systems. In: Santos, G.A. and Camargo, F.A.O., Eds., Fundamentals of Soil Organic Matter: Tropical and Subtropical Ecosystems, Genesis, Porto Alegre, 1-8.

[45] Duxbury, J.M., Smith, M.S. and Doran, J.M. (1989) Soil Organic Matter as a Source and a Sink of Plant Nutrients. In: Coleman, D.C., Oades, J.M. and Uehara, G., Eds., Dynamics of Soil Organic Matter in Tropical Ecosystems, Volume 2, University of Hawai, Honolulu, 33-67.

[46] Sollins, P., Homann, P. and Caldwell, B.A. (1996) Stabilization and Destabilization of Soil Organic Matter: Mechanisms and Controls. Geoderma, 74, 65-105. http://dx.doi.org/10.1016/S0016-7061(96)00036-5

[47] Scherer, E.E., Nadal, R. and Castilhos, E.G. (1986) Use of Poultry Manure and Phosphate Fertilizer in Corn. EMPASC, Florianópolis, 36.

[48] Cheverry, C., Menetrier, Y. and Borloy, J. (1986) Distribution of Pig Slurry and Fertilizer. EMPASC, Chapecó, 432.

[49] Siqueira, O.J.F., Scherer, E.E. and Tassinari, G. (1981) Recommendations for Fertilizing and Liming for Studies of Rio Grande do Sul and Santa Catarina. EMBRAPA-CNPT, Passo Fundo, 100.

[50] Sutaryo, S., Ward, A. and Moller, H.B. (2012) Thermophilic Anaerobic Co-Digestion of Separated Solids from Acidified Dairy Cow Manure. Bioresource Technology, 114, 195-200. http://dx.doi.org/10.1016/j.biortech.2012.03.041

[51] Scherer, E.E., Castilhos, E.G. and Aita, C. (1986) Using Liquid Swine Manure as a Nitrogen Source for Corn and Beans. EMPASC, Chapecó, 4.

[52] Queiroz, M.I. (2007) The Kinetics of the Removal of Nitrogen and Organic Matter from Parboiled Rice Effluent by Cyanobacteria in a Stirred Batch Reactor. Bioresource Technology, 98, 2163-2169. http://dx.doi.org/10.1016/j.biortech.2006.08.034

[53] Barnabé, M.C. (2001) Production and Chemical Composition of Brachiaria brizantha cv. Marandu Fertilized with Swine Manure. Master's Thesis, School of Veterinary Medicine, Federal University of Goiás, Goiania, 85 p.

[54] Henklain, J.C., Parra, M.S., Hamakawa, P.J. and Oliveira, E. (1994) Effect of Pig Slurry on Soil Hydraulic Properties. In: Proceedings of the Brazilian Meeting on Management and Conservation of Soil and Water, SBCS, Florianópolis, 216-217.

[55] Jandl, G., Leinweber, P. and Schulten, H.R. (2007) Origin and Fate of Soil Lipids in a Phaeozem under Rye and Maize Monoculture in Central Germany. Biology and Fertility of Soils, 43, 321-332. http://dx.doi.org/10.1007/s00374-006-0109-2

[56] Fierros, F.D., Villar, M.C. and Gil, F. (1987) Laboratory Study of the Availability of Nutrients in Physical Fractions of Cattle Slurry. The Journal of Agricultural Science, 108, 353-359. http://dx.doi.org/10.1017/S0021859600079375

[57] Matos, A.T., Sediyama, M.A.N. and Freitas, S.P. (1997) Chemical and Microbiological Soil Characteristics Influenced by the Application of Liquid Swine Manure. Ceres Journal, 254, 399-410.

[58] Schimidt, L.T., Dias, P.F., Souto, S.M. and Zanine, A.M. (2003) Effect of Manure and Sampling Dates on the Accumulation of Nutrients in the Soil Surface Layer. Pasturas Tropicales, 25, 24-27.

[59] Zanine, A.M., Schimidt, L.T., Dias, P.F. and Souto, S.M. (2003) Effect of Different Doses of Cattle Slurry in the pH and Mineral Composition of a Planosol Grown with Grasses of the Genera Cynodon and Digitaria. Pasturas Tropicales, 26, 37-41.

[60] Ceretta, C.A., Durigon, R. and Basso, C.J. (2003) Chemical Characteristics of Soil under Application of Liquid Swine Manure on Natural Pasture. Brazilian Agricultural Research, 38, 729-735.

[61] Tunney, H. (1975) The Ecological Soil Management. Proceedings of the 3rd International Symposium on Livestock Wastes, American Society of Agricultural Engineers, 1975, 594-597.

[62] Chateaubriand, A.D., Loureiro, B.T. and Caixeta, T.J. (1989) Effect of Swine Manure Applied in Furrow Irrigation, in Maize ( Zea mays L.). Ceres Journal, 36, 264-277.

[63] Mugwira, L.M. (1976) Effects of Dairy Cattle Manure on Millet and Rye Forage and Soil Properties. Journal of Environment Quality, 8, 251-255. http://dx.doi.org/10.2134/jeq1979.00472425000800020024x

[64] Leirós, M.C., Gil-Soares, M.C. and Trasar-Cepeda, A. (1996) Soil Recovery at the Meirama Opencast Lignite Mine in Northwest Spain: A Comparison of the Effectiveness of Cattle Slurry and Inorganic Fertilizer. Water, Air, and Soil Pollution, 91, 109-124. http://dx.doi.org/10.1007/BF00280927 
[65] Konzen, E.A. (2000) Management Alternatives, Treatment and Use of Animal Manure in Integrated Production Systems. Embrapa Maize and Sorghum, Sete Lagoas, 32 p.

[66] Durigon, R., Ceretta, C.A., Basso, C.J., Barcellos, L.A.R. and Pavinato, O.S. (2002) Forage Production of Natural with the Use of Liquid Swine Manure Pasture. Brazilian Journal of Soil Science, 26, 983-999.

[67] Schimidt, L.T., Dias, P.F., Souto, S.M. and Zanine, A.M. (2003) Absorption and Accumulation of Nutrients in Tanzania Grass (Panicum maximum) in Response to Nitrogen as Cattle Manure. Pasturas Tropicales, 25, 10-16.

[68] Zanine, A.M., Schimidt, L.T., Dias, P.F. and Souto, S.M. (2003) Production and Quality of Guinea Grass (Panicum maximum) in Ages and Fertilized with N Rates of Cattle Manure. Pasturas Tropicales, 26, 132-143.

[69] Zanine, A.M., Dias, P.F. and Souto, S.M. (2004) Chemical-Chemical Composition of Grasses of the Genus Cynodon and Digitaria in Response to Different Doses of Nitrogen in the Form of Cattle Manure. Pasturas Tropicales, 26, 1518 .

[70] Adeli, A., Varco, J.J. and Sistani, K.R. (2005) Effects of Swine Lagoon Effluent Relative to Commercial Fertilizer Application on Warm-Season Forage Nutritive Value. Agronomic Jounal, 97, 408-417. http://dx.doi.org/10.2134/agronj2005.0408

[71] Medeiros, L.U., Rezende, A.V., Valeriano, A.R., Vieira, P.F. and Junior, A.L.G. (2005) Nutritional Value of Fertigation Pasture with Pig Slurry. In: Proceedings of the XXXXII Annual Meeting of the Brazilian Society of Animal Science, UFG/GO, Goiânia, 28-32.

[72] Medeiros, L.U., Rezende, A.V., Valeriano, A.R., Vieira, P.F. and Junior, A.L.G. (2005) Agronomic Traits of Brachiaria brizantha Fertirriragada with Pig Slurry. In: Proceedings of the XXXXII Annual Meeting of the Brazilian Society of Animal Science, UFG/GO, Goiânia, 71-76.

[73] Medeiros, L.U., Rezende, A.V., Valeriano, A.R., Vieira, P.F. and Junior, A.L.G. (2007) Production and Quality of Forage Fertiirrigada Marandugrass with Pig Slurry. Journal of Animal Science, 36, 309-318.

[74] Zanine, A.M., Dias, P.F. and Souto, S.M. (2005) Influence of Nitrogen Fertilizer in the Form of Cattle Manure on Dry Matter and Nutrients Accumulated in Roots of Forage Grasses. Research and Development, 5, 1-18.

[75] Arruda, N.V.M., Abreu, J., Amaral, J.L. Oliveira, A.A., Coelho, F.P. and Santos, C.E. (2008) Production of Dry Grass (Brachiaria brizantha cv. Marandu) Stocking during Periods of Drought and Water. Biodiversity Journal, 7, 11-25.

[76] Minerz, G.R., Agnolin, C.A., Diehl, M. and Massarid, P.B. (2007) Structural Composition and Accumulation Rate in Grazing Elephant Grass Managed Conventionally or Agroecological Way. Brazilian Journal of Agroecology, 22, 1523 1526.

[77] Zanine, A.M., Dias, P.F. and Souto, S.M. (2006) Multivariate Analysis Applied in the Evaluation of Tropical Forage Grasses Fertilized with Cattle Manure. Journal of Rural University of Life sciences, 26, 28-34.

[78] Morrison, D.F. (1976) Multivariate Statistical Methods. McGraw-Hill Company, New York, 214 p.

[79] Furtado, D. (1999) Multivariate Analysis. UFLA, Minas Lavras, 400 p.

[80] Khattree, R. and Naik, D.N. (2000) Multivariate Data Reduction and Discrimination with SAS® Software. SAS Institute, North Carolina, $559 \mathrm{p}$.

[81] Zanine, A.M., Dias, P.F. and Souto, S.M. (2007) Use of Discriminant Functions for Comparison of Cultivars of the Genera Cynodon and Digitaria for Production of Dry Matter and Macronutrient Content. Archivos Latinoamericanos de Producción Animal, 15, 110-116.

[82] Zanine, A.M., Dias, P.F. and Souto, S.M. (2008) Evaluation of Tanzania Grass (Panicum maximum) by Multivariate Analysis. Journal of Animal Health and Production, 9, 179-189. 